\title{
Deoxyribonucleic Acid Relatedness between Selected Members of the Genus Aquaspirillum by Slot Blot Hybridization: Aquaspirillum serpens (Mueller 1786) Hylemon, Wells, Krieg, and Jannasch 1973 Emended to Include Aquaspirillum bengal as a Subjective Synonym
}

\author{
M. F. BOIVIN, V. L. MORRIS, E. C. M. LEE-CHAN, AND R. G. E. MURRAY* \\ Department of Microbiology and Immunology, University of Western Ontario, London, Ontario N6A 5Cl, Canada
}

\begin{abstract}
Deoxyribonucleic acid relatedness of five strains of Aquaspirillum serpens and also four other species of this genus was assessed by slot blot hybridization. A high degree of genetic relatedness was evident among the strains within the species $A$. serpens, but a low degree of relatedness was shown between the species $A$. serpens, $A$. sinuosum, $A$. itersonii, and $A$. putridiconchylium. Hybridization homology indicated that $A$. bengal is a subjective synonym for $A$. serpens and should not have separate species status; therefore, the description of $A$. serpens is emended accordingly. The strains that grow optimally at higher temperatures $\left(41^{\circ} \mathrm{C}\right)$ and produce brown pigments in the presence of some amino acids may be considered varietal and are referred to as $A$. serpens biovar bengal. This study demonstrates the usefulness of slot blot hybridization for quickly assessing the relatedness of different taxonomic groups of bacteria.
\end{abstract}

The application of molecular genetic techniques to bacterial systematics has initiated an extensive reordering of the taxonomic groupings of many bacteria which had previously been grouped according to phenotypic data. The goal is to provide means for classifying bacteria into phylogenetic taxa. Extended assessments of bacterial genera and new isolates will require simpler, rapid methods for both deoxyribonucleic acid (DNA) and ribonucleic acid (RNA) homology studies that are suitable for less sophisticated laboratories.

The helically curved spirilla have undergone extensive taxonomic regrouping in the past decade because genetic information modifies the previous phenotypic arrangements. The first edition of Bergey's Manual of Systematic Bacteriology (13) now places members of this group into three genera (Aquaspirillum, Oceanospirillum, and Spirillum) according to Hylemon et al. (9). The wide range of DNA base compositions indicated that a single genus was inappropriate for these organisms. The genus Aquaspirillum (mol\% $\mathrm{G}+\mathrm{C}$ range of 49 to 66 ) is still based largely on phenotype. DNA/DNA hybridization studies have not been done to support or reject all 17 species presently recognized within this genus, except in the case of $A$. autotrophicum versus $A$. dispar (1).

Slot blot hybridization, a modification of dot blot hybridization (10), appears to be an ideal candidate as a rapid method for comparing multiple DNA samples from different strains of bacteria. Dot blot hybridization has already been tested against a spectrophotometric DNA hybridization assay for examining the relatedness between Mycobacterium leprae or Mycobacterium lepraemurium and other selected bacteria (2).

In this study, we have used slot blot hybridization to examine the DNA relatedness between representative strains of five different species of the genus Aquaspirillum, as compared to an Escherichia coli strain and a Campylobacter jejuni strain as distantly related controls. We have

\footnotetext{
* Corresponding author.
}

also examined five selected strains from the species Aquaspirillum serpens to determine whether they do in fact belong within the same species group, because these strains are of similar phenotype (Table 1). Three of them are variants of the $A$. serpens VH strain (9), and they differ in minor ways. Strain VHL has lost the hexagonal protein layer on the surface of the cells, while the Straight Rhodes strain (SRS) is not helical; the A. serpens ATCC $12638^{\mathrm{T}}$ ( $\mathrm{T}=$ type strain) does not normally possess a surface array, and strains VHA and MW5 possess single or double-layered surface arrays, respectively $(11,12)$. We needed the assurance provided by genetic data that the strains whose surface arrays we were studying did belong in the species $A$. serpens.

\section{MATERIALS AND METHODS}

Bacterial strains and culture conditions. The strains used in the homology experiments and their sources are listed in Table 2. All $A$. serpens strains were maintained at $30^{\circ} \mathrm{C}$ on peptone-succinate-salts agar slants in screw-capped tubes (9) and were subcultured every 2 weeks. Other Aquaspirillum species were maintained on peptone-succinate-yeast extract medium containing $0.15 \%$ agar in screw-capped tubes (3). These cultures were maintained at $30^{\circ} \mathrm{C}$, with the exception of $A$. bengal which was maintained at $41^{\circ} \mathrm{C}$. $\mathrm{KOH}$ was used to adjust the $\mathrm{pH}$ in all of the above media, since spirilla have been reported to be sensitive to low concentrations of $\mathrm{Na}^{+}$ (19). The $C$. jejuni strain was maintained at $42^{\circ} \mathrm{C}$ on brucella agar slants (Difco Laboratories) with weekly subculturing. The $E$. coli $\mathrm{B}$ strain was maintained at $37^{\circ} \mathrm{C}$ on nutrient agar slants (Difco).

DNA isolation and preparation. Overnight $100-\mathrm{ml}$ broth cultures from a second 24-h serial transfer were used for DNA isolations from each of the strains. Cells were washed once with $1 \times \mathrm{SSC}(0.15 \mathrm{M} \mathrm{NaCl}, 0.015 \mathrm{M}$ trisodium citrate [pH 7.0]) and suspended in $3 \mathrm{ml}$ of STE buffer $(0.1 \mathrm{M} \mathrm{NaCl}$, $0.02 \mathrm{M}$ Tris, 0.01 M EDTA [pH 7.4]). DNA samples were prepared according to a modified method of Cohen et al. (7) 
TABLE 1. Observed characteristics of various strains of $A$. serpens and of $A$. bengal ATCC 27641

\begin{tabular}{|c|c|c|c|c|c|c|}
\hline \multirow{2}{*}{ Characteristics } & \multicolumn{6}{|c|}{ Strains } \\
\hline & $\begin{array}{l}\text { ATCC } \\
12638\end{array}$ & MW5 & VHA & VHL & SRS & $\begin{array}{l}\text { ATCC } \\
27641\end{array}$ \\
\hline Helical shape & + & + & + & + & - & + \\
\hline Acid from sugars & - & - & - & - & - & - \\
\hline \multicolumn{7}{|l|}{ Growth on or in } \\
\hline EMB & + & + & + & + & + & + \\
\hline MacConkey & - & + & + & + & + & - \\
\hline TSI & - & + & + & + & + & + \\
\hline MRVP broth & - & + & - & + & - & - \\
\hline $\begin{array}{l}\text { Growth in presence of } \\
1 \% \text { glycine }\end{array}$ & - & - & - & - & - & - \\
\hline $\begin{array}{l}\text { RS (regular surface array) } \\
\text { layer }\end{array}$ & - & $2+a$ & + & - & + & + \\
\hline Optimum growth at $41^{\circ} \mathrm{C}$ & - & - & - & - & - & + \\
\hline \multicolumn{7}{|l|}{$\begin{array}{l}\text { Water soluble pigment } \\
\text { formed in the } \\
\text { presence of }\end{array}$} \\
\hline $0.1 \%$ tyrosine & - & $\mathrm{nt}^{b}$ & nt & nt & nt & + \\
\hline $0.1 \%$ tryptophan & - & nt & nt & nt & nt & + \\
\hline
\end{tabular}

${ }^{a} 2+$, Double-layered surface array.

${ }^{b}$ nt, Not tested.

as described by MacInnes et al. (15). This involved digestion by pronase and lysis of the cells with sodium dodecyl sulfate, followed by phenol-chloroform extractions and dialysis. The DNA samples were subjected to agarose gel electrophoresis to test for the presence of extrachromosomal plasmid DNA (17), but no plasmid DNA was detected among the Aquaspirillum strains used (data not shown). The DNA samples were then digested overnight with EcoRI enzyme (Boehringer-Mannheim) at a concentration of $1 \mathrm{U}$ of EcoRI per $\mu \mathrm{g}$ of DNA according to the manufacturer's instructions. The RNA was removed by digestion with ribonuclease (bovine pancreatic, type A, boiled for $10 \mathrm{~min}$; Worthington) which was added at a concentration of $3 \mu \mathrm{g}$ of ribonuclease per $\mu \mathrm{g}$ of DNA at $37^{\circ} \mathrm{C}$ overnight. Phenol-chloroform extractions, followed by chloroform extractions were done as before. The DNA was recovered by ethanol precipitation. DNA concentrations were determined by the diphenylamine assay of Burton (6).

Slot blot hybridization. Slot blot hybridization was performed by the method of Kafatos et al. (10), with slight modifications. Serial 10-fold or 2-fold dilutions of DNA samples were prepared in $1 \mathrm{M}$ ammonium acetate after having been denatured for $30 \mathrm{~min}$ in $0.3 \mathrm{M} \mathrm{NaOH}$ at room temperature. Samples $(50 \mu \mathrm{l})$ were applied to a preequilibrated nitrocellulose sheet placed on a slot blot apparatus (Schleicher \& Schuell Inc.). The nitrocellulose sheet was soaked for $10 \mathrm{~min}$ in $4 \times \mathrm{SSC}$ and then baked for $2 \mathrm{~h}$ in a vacuum oven at $80^{\circ} \mathrm{C}$. Sheets were preannealed for $24 \mathrm{~h}$ at $42^{\circ} \mathrm{C}$ with preannealing buffer $(3 \times$ SSC, $50 \%$ formamide, 200 $\mu \mathrm{g}$ of yeast RNA per $\mathrm{ml}, 20 \mu \mathrm{g}$ of denatured salmon sperm DNA per $\mathrm{ml}, 1 \times$ Denhardt buffer [3\% Ficoll, 3\% polyvinyl pyrrolidone, $3 \%$ bovine serum albumin]). ${ }^{32} \mathrm{P}$-labeled DNA probes were prepared from 1- $\mu$ g DNA samples by nick translation $(16,18)$. Before hybridization, each of the ${ }^{32} \mathrm{P}$ labeled DNA probes was boiled for $10 \mathrm{~min}$.
Hybridization temperatures between 40 and $70^{\circ} \mathrm{C}$ were tested at $10^{\circ} \mathrm{C}$ intervals; 40 to $42^{\circ} \mathrm{C}$ was found to be optimum for Aquaspirillum DNAs. Each DNA probe was then hybridized separately to a single filter at approximately $2 \times 10^{4}$ $\mathrm{cpm} / \mathrm{cm}^{2}$ of filter and incubated at $42^{\circ} \mathrm{C}$ for $48 \mathrm{~h}$ in annealing buffer. Blots were washed three times with $2 \times \mathrm{SSC}$ at room temperature and then washed twice at $50^{\circ} \mathrm{C}$ with $0.1 \times \mathrm{SSC}+$ $0.1 \%$ sodium dodecyl sulfate. The blots were then rinsed consecutively through two baths of $0.1 \times \mathrm{SSC}+0.1 \%$ sodium dodecyl sulfate and then through five baths of $0.1 \%$ $\mathrm{SSC}$. The resulting slot blots were visualized by autoradiography as described by Swanstrom and Shank (20).

Densitometric scanning. Densitometric scanning of autoradiographs was done using a Beckman UV-visible spectrophotometer with a DU-8 gel-scanning system.

Controls. (i) Salmon sperm DNA was included in all experiments as a nonhomologous control. (ii) In the DNA trapping experiment the effect of various concentrations of nonhomologous DNA upon the signal being received from homologous DNA annealed to a ${ }^{32} \mathrm{P}$-labeled probe was assessed. In this experiment, DNA from $A$. serpens ATCC 12638 was spotted in 10 -fold dilutions on a nitrocellulose filter. Each dilution of this DNA was then mixed with 1-, 2-, and $3-\mu \mathrm{g}$ amounts of salmon sperm DNA and spotted in separate columns on the filter. The filter was hybridized with a probe made from $A$. serpens ATCC 12638 DNA.

\section{RESULTS}

The DNAs from five strains of $A$. serpens were spotted in twofold dilutions on a nitrocellulose filter and hybridized with $A$. serpens ATCC $12638 \mathrm{DNA}$ as the probe. The degree of hybridization among all five strains was similar to Fig. 1, lane A, rows 1 to 8 , which contained the homologous $A$. serpens ATCC 12638 DNA. Taking into account the dilution factor, it can be visually estimated that the strains share at least $50 \%$ homology.

The DNAs from five different species of the genus Aquaspirillum were compared in a series of five blots. The DNAs from each species were spotted in 10-fold dilutions in an identical order on each nitrocellulose filter. In a similar manner, DNAs from the $C$. jejuni and $E$. coli B strains were also included on each filter. Each filter was then hybridized with a different probe made from one of the Aquaspirillum species. In this manner, reciprocal hybridizations were done between all of the Aquaspirillum species examined.

In Fig. 2a, A. sinuosum ATCC 9786 DNA was used as the probe, and it can be seen that the greatest amount of hybridization occurred with the homologous $A$. sinuosum DNA in lane B, rows 1 to 5 . Only low levels of hybridization could be observed with the other Aquaspirillum species when compared to that occurring between $E$. coli $\mathrm{B}$ (Fig. 2a, lane A, rows 11 to 15 ) and $A$. sinuosum.

In Fig. 2b, A. putridiconchylium ATCC 15279 DNA was used as the probe, and the greatest homology can be seen with the $A$. putridiconchylium DNA spotted in lane B, rows 6 to 10. Again, no marked degree of homology was observed with any of the other species, although a slight amount occurred with the $A$. serpens and $A$. bengal DNAs.

A probe made from $A$. itersonii ATCC 11331 DNA was used in Fig. 2c. Again the only appreciable amount of homology observed was with the homologous $A$. itersonii DNA in lane $\mathrm{C}$, rows 1 to 5 .

In Fig. 2d, a probe made from A. serpens ATCC 12638 DNA was used. In this case, the degree of hybridization observed between $A$. serpens DNA (lane A, rows 1 to 5) and 
TABLE 2. Strains used in DNA hybridization studies

\begin{tabular}{|c|c|c|c|}
\hline Bacteria & $\begin{array}{l}\text { Culture } \\
\text { collection no. }\end{array}$ & $\begin{array}{l}\text { Other strain } \\
\text { designations }\end{array}$ & Comments \\
\hline A. serpens & ATCC $12638^{a}$ & & Type species for the genus. Normally lacks a surface array. \\
\hline A. serpens & MDUWO 377 & MW5 & Possesses double-layered surface array \\
\hline A. serpens & MDUWO 369 & VHA & Possesses single-layered surface array \\
\hline A. serpens & MDUWO 368 & VHL & Derivative of VH strain lacking a surface array. \\
\hline A. serpens & MDUWO 614 & SRS & Derivative of VH strain lacking a helical shape. \\
\hline A. sinuosum & ATCC $9786^{\mathrm{T}}$ & & Retained in MDUWO as UWO 642 . \\
\hline A. itersonii & ATCC 11331 & & Retained in MDUWO as UWO 644. \\
\hline A. bengal & ATCC $27641^{\mathrm{T}}$ & & $\begin{array}{l}\text { Strain used was received from N. R. Krieg (Department of Biology, } \\
\text { Virginia Polytechnic Institute and State University, Blacksburg). }\end{array}$ \\
\hline A. butridiconchylium & ATCC $15279^{\mathrm{T}}$ & & $\begin{array}{l}\text { Strain used was received from N. R. Krieg (Department of Biology, } \\
\text { Virginia Polytechnic Institute and State University, Blacksburg). }\end{array}$ \\
\hline C. jejuni & MDUWO 1210 & & Clinical isolate from Victoria Hospital, London Ontario. \\
\hline E. coli B & ATCC 15669 & & Retained in MDUWO as UWO 721. \\
\hline
\end{tabular}

a ATCC, American Type Culture Collection, Rockville, Md.; MDUWO, Department of Microbiology and Immunology Culture Collection, University of Western Ontario, London, Ontario; strains received from the culture collections indicated were used unless otherwise stated. T, Type strain for the species.

A. bengal DNA (lane A, rows 6 to 10 ) was similar to the last dilution level. Since 10 -fold dilutions were used, this indicates that $A$. bengal and $A$. serpens share at least $10 \%$ homology. When the reciprocal hybridization experiment was done, using $A$. bengal ATCC 27641 DNA as the probe, again there was a similar degree of hybridization occurring between the two species $A$. bengal and $A$. serpens (Fig. 2e). Densitometric scanning of the autoradiographs was done to more closely determine the degree of homology between $A$. bengal and $A$. serpens. At least $60 \%$ homology was evident, because the unsaturated bands on both autoradiographs showed values ranging from 59 to $73 \%$ homology. With the

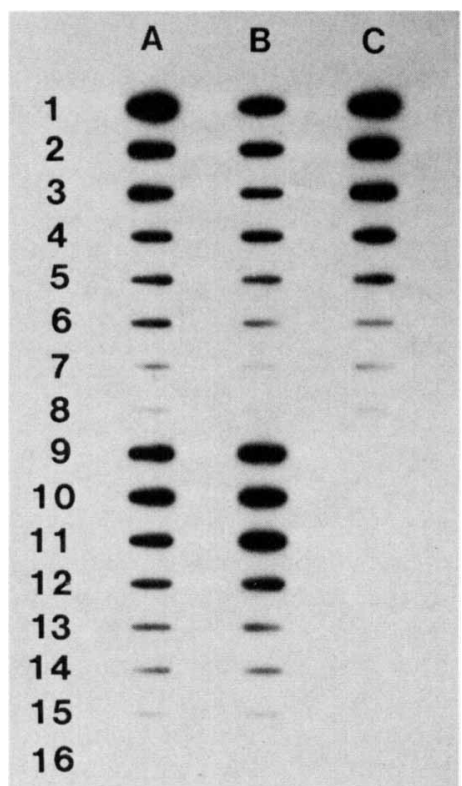

FIG. 1. Comparison of five strains of $A$. serpens by slot blot hybridization. DNA samples were spotted in twofold dilutions starting with $0.1 \mu \mathrm{g}$ of DNA onto a nitrocellulose filter which was then hybridized with $A$. serpens ATCC 12638 DNA as a probe. Lane A, rows 1 to $8, A$. serpens ATCC 12638; lane $\mathrm{B}$, rows 1 to $8, A$. serpens MW5; lane $C$, rows 1 to $8, A$. serpens VHA; lane A, rows 9 to $16, A$. serpens VHL; lane B, rows 9 to $16, A$. serpens SRS; lane $\mathrm{C}$, rows 9 to 16 , Salmon sperm DNA. The X-ray film was exposed for 2 days. other Aquaspirillum species, there was at least a 100 -fold difference in the level of hybridization against either probe, indicating less than $1 \%$ homology.

The results of the DNA trapping experiment are shown in Fig. 3. The intensities of the signals obtained from the mixtures of homologous and nonhomologous DNAs, were identical to the signal seen in the corresponding dilutions of completely homologous DNA. This demonstrates that, in the range of dilutions used in our experiments, there was no nonspecific trapping of the probe onto the filter nor any quenching of the ${ }^{32} \mathrm{P}$ signal by excess amounts of nonhomologous DNA.

\section{DISCUSSION}

Comparison of the A. serpens strains ATCC 12638, MW5, VHA, VHL, and SRS, against the type strain probe, showed that there were no obvious genotypic differences to reflect the differences in their phenotypes. These strains can therefore be considered as a single genetic species. The limit of resolution of slot blot hybridization is not sufficient to examine the genetic nature of the different phenotypic characters expressed in these strains; therefore, future studies will likely have to resort to restriction endonuclease analysis (4) to do this.

Comparison of the five Aquaspirillum species by slot blot hybridization, using probes involving the whole genome, provides information on the relatedness of these organisms. It is clear the the DNA homology of the species $A$. serpens and $A$. bengal, represented by their type strains, does not warrant separate species status. Furthermore, Woese et al. (22) compared $16 \mathrm{~S}$ ribosomal RNA oligonucleotide sequences from a wide range of gram-negative bacteria, including a number of Aquaspirillum species in particular $A$. serpens and $A$. bengal. They found these latter two to be most closely related among the aquaspirilla studied, with an $\mathrm{S}_{\mathrm{AB}}$ value of 0.93 . Woese and his colleagues state that this is high enough for $A$. serpens and $A$. bengal to be considered strains of the same species. Therefore, we propose that $A$. bengal be declared a subjective synonym for $A$. serpens.

The genus Aquaspirillum appears to be quite broad considering that the levels of hybridization observed between these species was often no greater than or even less than the level of hybridization which occurred with $E$. coli $\mathrm{B}$. Woese et al. found a great degree of phylogenetic heterogeneity among the Aquaspirillum species used in their studies in- 

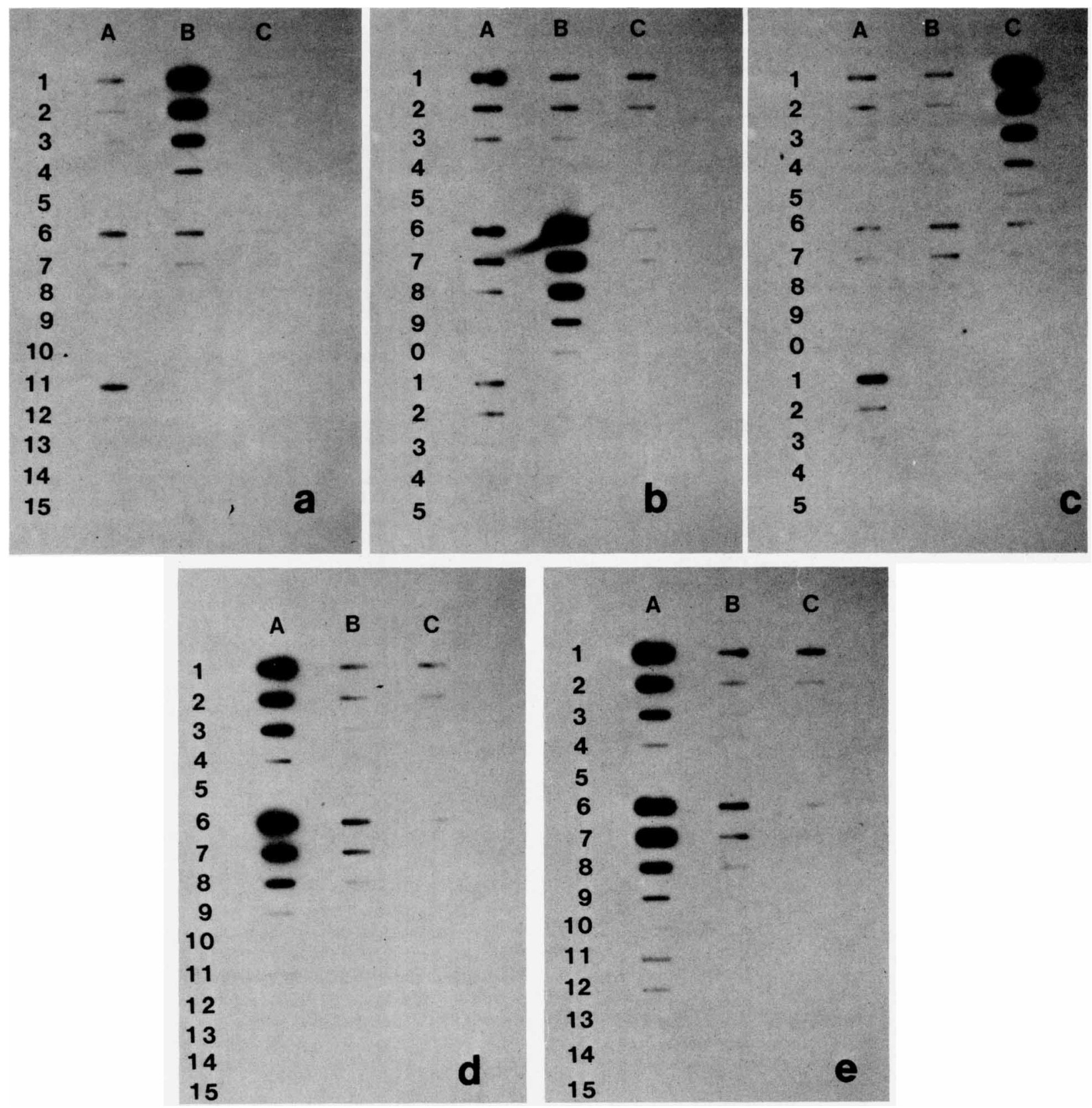

FIG. 2. Comparison of five Aquaspirillum species by a series of slot blot hybridizations. DNA samples were spotted identically on each nitrocellulose filter in 10-fold dilutions starting with $1 \mu \mathrm{g}$ of DNA each. Lane A, rows 1 to 5 , A. serpens ATCC 12638; lane B, rows 1 to 5, A. sinuosum ATCC 9876; lane C, rows 1 to 5, A. itersonii ATCC 11331; lane A, rows 6 to 10, A. bengal ATCC 27641; lane B, rows 6 to 10, A. putridiconchylium ATCC 15279; lane C, rows 6 to $10, C$. jejuni UWO 1210; lane A, rows 11 to $15, E$. coli $\mathrm{B}$ ATCC 15669 ; lane B, rows 11 to 15 , salmon sperm DNA; the X-ray film was exposed for 3 days. (a) $A$. sinuosum ATCC 9876 DNA was used as a probe. (b) $A$. putridiconchylium ATCC 15279 DNA was used as a probe. (c) A. itersonii ATCC 11331 DNA was used as a probe. (d) A. serpens ATCC 12638 DNA used as a probe. (e) $A$. bengal ATCC 27641 DNA used as a probe.

volving $16 \mathrm{~S}$ ribosomal RNA cataloging $(21,22)$. The relation of $A$. itersonii and A. polymorphum to the genus Azospirillum has also been indicated by ribosomal RNA/DNA hybridization studies (8).

We have shown that slot blot hybridization can provide reliable visual information about the degree of DNA/DNA homology between different bacteria as long as optimum conditions are employed. The amounts of DNA applied to the filter must be standardized, saturation of the filter must be avoided, and an optimum temperature of hybridization must be chosen. The DNA trapping experiment demonstrates the specificity of this method for homologous DNA even in mixtures containing low concentrations of that DNA. Indeed, Kafatos et al. (10) found that with dot blot hybridization they could obtain reproducible estimates of relative concentrations for sequences accounting for less than $1: 10^{-4}$ of a mixture.

While the information gained from slot blot hybridization 


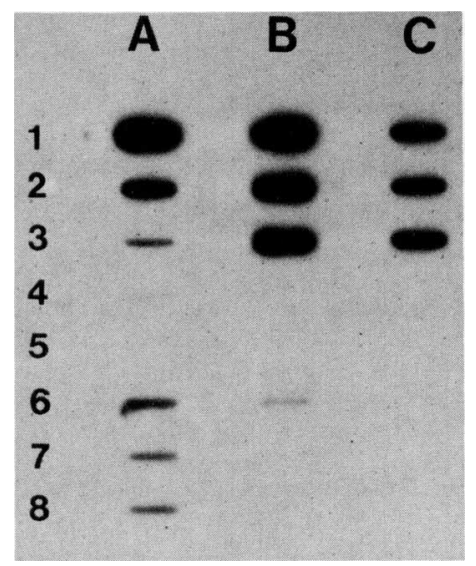

FIG. 3. DNA trapping experiment for slot blot hybridization. $A$. serpens ATCC 12638 DNA was spotted alone or with salmon sperm DNA onto a nitrocellulose filter and hybridized with an $A$. serpens ATCC 12638 probe as described in the text. Lane A, rows 1 to $4, A$. serpens DNA in $10^{-1}, 10^{-2}, 10^{-3}$, and $10^{-4} \mu \mathrm{g}$ amounts, respectively; lane B, rows 1 to $3, A$. serpens DNA $\left(10^{-1} \mu \mathrm{g}\right)$ mixed with 1 , 2 , and $3 \mu \mathrm{g}$ of salmon sperm DNA, respectively; lane $\mathrm{C}$, rows 1 to 3 , A. serpens DNA $\left(10^{-2} \mu \mathrm{g}\right)$ mixed with 1,2 , and $3 \mu \mathrm{g}$ of salmon sperm DNA; lane A, rows 6 to $8, A$. serpens DNA $\left(10^{-3} \mu \mathrm{g}\right)$ mixed with 1,2 , and $3 \mu \mathrm{g}$ of salmon sperm DNA; lane B, rows 6 to $8, A$. serpens DNA $\left(10^{-4} \mu \mathrm{g}\right)$ mixed with 1,2 , and $3 \mu \mathrm{g}$ of salmon sperm DNA; the $x$-ray film was exposed for 3 days.

is only semiquantitative, the technique is still extremely useful for taxonomically grouping bacteria into species within a genus. No previous genetic information needs to be known for the organisms being examined, and reciprocal hybridizations can be done relatively quickly. Depending upon whether 10-fold or 2-fold dilutions are used, one can visually estimate at least 10 or $50 \%$ homology between different DNA samples. This is sufficient for many taxonomic purposes and avoids the tedious chore of cutting out the slots from the nitrocellulose sheet to be counted in a scintillation machine. Slot blot hybridization also lends itself well to densitometric scanning, which allows a closer determination of homology when desired. Conceivably, slot blot hybridization could easily be adapted for ribosomal RNA/DNA hybridization studies, allowing higher taxonomic groups to be examined as well.

Nomenclatural considerations. The only nomenclatural requirement is that $A$. serpens takes precedence over $A$. bengal; the phenotypic distinction is varietal and infrasubspecific. ATCC 27641 , formerly the type strain for $A$. bengal, should now be recognized as representing $A$. serpens biovar bengal and distinguishable from strains of $A$. serpens biovar serpens by a high optimum temperature for growth $\left(41^{\circ} \mathrm{C}\right)$ and by the formation of brown pigments in the presence of $0.1 \%$ of tyrosine and of tryptophan in media (Table 1). The apparent subjective synonymy of $A$. serpens (Muller 1786) Hylemon, Wells, Krieg, and Jannasch 1973 (9) and $A$. bengal Kumar, Banerjee, Bowdre, McElroy, and Krieg 1974 (14) requires emendation of the description of $A$. serpens to allow inclusion of the strains of the biovar bengal.

Description of the species. A. serpens (Muller 1786) Hylemon, Wells, Krieg, and Jannasch 1973 (9) should be emended to include: cell diameter, 0.6 to $1.2 \mu \mathrm{m}$; optimum growth temperature, 35 to $41^{\circ} \mathrm{C}$; brown pigments may be produced in media containing tyrosine or tryptophan; and $\mathrm{G}+\mathrm{C}$ values of the DNA range from 49 to $52 \mathrm{~mol} \%$.

\section{ACKNOWLEDGMENTS}

We greatly appreciate the help of Geoff Ralling of the Department of Microbiology and Immunology, University of Western Ontario, London, Ontario, in screening for plasmid DNA among the DNA samples. We also thank Doug Kuntz of the Department of Biochemistry, University of Western Ontario, for his help with the densitometric scanning of autoradiographs.

This study was supported by grants from the Medical Research Council of Canada.

\section{LITERATURE CITED}

1. Aragno, M., and H. G. Schlegel. 1978. Aquaspirillum autotrophicum, a new species of hydrogen-oxidizing, facultatively autotrophic bacteria. Int. J. Syst. Bacteriol. 28:112-116.

2. Athwal, R. S., S. S. Deo, and T. Imaeda. 1984. Deoxyribonucleic acid relatedness among Mycobacterium leprae, Mycobacterium lepraemurium, and selected bacteria by dot blot and spectrophotometric deoxyribonucleic acid hybridization assays. Int. J. Syst. Bacteriol. 34:371-375.

3. Beveridge, T. J., and R. G. E. Murray. 1974. The superficial macromolecular arrays on the cell wall of Spirillum putridiconchylium. J. Bacteriol. 119:1019-1038.

4. Bradbury, W. C., R. G. E. Murray, C. Mancini, and V. L. Morris. 1985. Bacterial chromosomal restriction endonuclease analysis of the homology of Bacteroides species. J. Clin. Microbiol. 21:24-28.

5. Buchanan, R. E., and N. E. Gibbons (ed.). 1974. Bergey's manual of determinative bacteriology, 8th ed. The Williams \& Wilkins Co., Baltimore, Md.

6. Burton, K. 1968. Determination of DNA concentration with diphenylamine. Methods Enzymol. 12B:163-166.

7. Cohen, J., J. E. Majors, and H. E. Varmus. 1979. Organization of mouse mammary tumor virus-specific DNA endogenous to Balb/c mice. J. Virol. 32:483-496.

8. De Smedt, J., M. Bauwens, R. Tijtgat, and J. De Ley. 1980. Intra- and intergeneric similarities of ribosomal ribonucleic acid cistrons of free-living, nitrogen-fixing bacteria. Int. J. Syst. Bacteriol. 30:106-122.

9. Hylemon, P. B., J. S. Wells, N. R. Krieg, and H. W. Jannasch. 1973. The genus Spirillum: a taxonomic study. Int. J. Syst. Bacteriol. 23:340-380.

10. Kafatos, F. C., C. W. Jones, and A. Efstratiadis. 1979. Determination of nucleic acid sequence homologies and relative concentrations by a dot blot hybridization procedure. Nucleic Acids Res. 7:1541-1552.

11. Kist, M. L., and R. G. E. Murray. 1984. Components of the regular surface array of Aquaspirillum serpens MW5 and their assembly in vitro. J. Bacteriol. 157:599-606.

12. Koval, S. F., and R. G. E. Murray. 1984. The isolation of surface array proteins from bacteria. Can. J. Biochem. Cell. Biol. 62:1181-1189.

13. Krieg, N. R. 1984. The genus Aquaspirillum, p. 72-90. In N. R. Krieg and J. G. Holt (ed.), Bergey's manual of systematic bacteriology, vol. 1. The Williams \& Wilkins Co., Baltimore.

14. Kumar, R., A. K. Banerjee, J. H. Bowdre, L. J. McElroy, and N. R. Krieg. 1974. Isolation, characterization, and taxonomy of Aquaspirillum bengal sp. nov. Int. J. Syst. Bacteriol. 24:453-458.

15. MacInnes, J. I., V. L. Morris, W. F. Flintoff, and C. A. Kozak. 1984. Characterization and chromosomal location of endogenous mouse mammary tumour virus loci in GR, NFS, and DBA mice. Virology 132:12-25.

16. Maniatis, T., E. F. Fritsch, and J. Sambrook. 1982. Molecular cloning -a laboratory manual. Cold Spring Harbor Laboratory, Cold Spring Harbor, N.Y.

17. Meyers, J. A., D. Sanchez, L. P. Elwell, and S. Falklow. 1976. Simple agarose gel electrophoretic method for the identification and characterization of plasmid deoxyribonucleic acid. J. Bacteriol. 127:1529-1537.

18. Rigby, P. W. J., M. Dieckmann, C. Rhodes, and P. Berg. 1977. Labeling deoxyribonucleic acid to high specific activity in vitro by nick translation with DNA polymerase I. J. Mol. Biol. 
113:237-251.

19. Skerman, V. B. D. 1967 . A guide to the identification of the genera of bacteria, 2nd ed., p. 126. The Williams \& Wilkins Co., Baltimore, Md.

20. Swanstrom, R., and P. R. Shank. 1978. X-ray intensifying screens greatly enhance the detection by autoradiography of the radioactive isotopes ${ }^{32} \mathrm{P}$ and ${ }^{125} \mathrm{I}$. Anal. Biochem. 86:184-192.
21. Woese, C. R., P. Blanz, R. B. Hespell, and C. M. Hahn. 1982. Phylogenetic relationships among various helical bacteria. Curr. Microbiol. 7:119-124.

22. Woese, C. R., W. G. Weisburg, B. J. Paster, C. M. Hahn, R. S. Tanner, N. R. Krieg, H. P. Koops, H. Harms, and E. Stackebrandt. 1984. The phylogeny of purple bacteria: the beta subdivision. System. Appl. Microbiol. 5:327-336. 